\title{
Irena Turonska
}

\section{Er dyreretsfilosofien en trussel mod det humanistiske menneskesyn}

I den vestlige verden har økologiorienterede filosoffer som f.eks. Peter Singer, Tom Regan, Hans Jonas og Arne Naess længe haft en fremtrædende rolle i den miljøfilosofiske og politiske debat. De har også tjent som inspirationskilde for miljø- og veganbevægelsen. Fra humanistisk side har man advaret imod, at disse filosoffer forsøger at erstatte den antropocentriske verdensopfattelse, der for en stor dels vedkommende blev formet igennem 1600- og 1700-tallet, med en biologisk verdensanskuelse.

Kritikerne mener at disse tænkere ikke alene argumenterer for en opvurdering af naturen men også forsøger sig med et paradigmeskifte i synet på mennesket.

En gængs anmærkning fra humanisterne er, at økologiorienterede filosoffers angreb på den moderne humanisme sker parallelt med en bølge af kritiske reaktioner imod oplysningsprojektet fra ideologier, der værner om retten til forskellighed. Disse postmoderne ideologier og økologibundne filo- soffer fremfører dog deres kritik imod oplysningshumanismen ud fra helt forskellige perspektiver. Postmodernisterne afviser humanismens universalistiske tænkning som essentialistisk og reducerende $\mathrm{i}$ forhold til forskellige samfunds, kulturers, gruppers og individers særlige træk. Til forskel fra de postmoderne forlader de økologiorienterede filosoffer ikke de store sammenhænge. De forsøger sig med en grundig genprøvning af det vesterlandske antropocentriske verdensbillede. Selv påbegynder de en alternativ stor fortælling, det biocentriske verdensbillede, og utopien om det perfekte økologiske samfund. Konflikten mellem humanisterne og økologiorienterede filosoffer sætter præg på hele den vesterlandske miljøetiske debat. I grunden handler konflikten om, hvem eller hvad der kan betragtes som et moralsk subjekt.

Eftersom det økologisketiske felt omfatter dyreretsteorierne, dybdeøkologien og flere andre retninger, som f.eks. etisk holisme og egalitarisk biocentrisme, vælger 
jeg $\mathrm{i}$ hovedsagen at konfrontere humanismen med dyreretsteorierne. Jeg vil i det følgende kort gennemgå to førende dyreretsfilosoffers hovedargumenter for at give alle dyr en etisk og juridisk status, men fokuserer på spørgsmålet om, hvordan nutidens humanister svarer på udfordringen fra dyreretsfilosofier. Jeg lader humanisterne Luc Ferry, Peter Kemp og Ingemar Nordin stå for kritikken af udfordrerne.

\section{Dyreretsfilosofferne reviderer den antropocentriske etik}

Dyreretsfilosofferne Peter Singer og Tom Regan har ambitioner om at affærdige en moralsk forskel mellem menneske og dyr. Men for at kunne overbevise om fortræffeligheden i deres argumenter, må de sørge for, at deres teorier ikke leder til endnu større urimeligheder end den cartesianske humanismes. Disse to filosoffer, som tilbyder legitimering af dyreretsaktivismen, tilnærmer sig spørgsmålet om, hvilken moralsk status man skal give dyr, og hvilke kriterier denne status forudsætter, fra to forskellige steder. Singer gør det ud fra utilitarismen og Regan ud

\section{Peter Singer: lige hensyn til dyrets og menneskets interesser}

Det klassisk utilitaristiske princip siger, at vi bør handle sådan, at vi maksimerernytten ellerlyksaligheden i verden. Jeremy Bentham, der udfærdigede princippet, indså, at den størst mulige lykke til det størst mulige antal individer også bør indbefatte dyrene, eftersom de ligesom mennesker kan lide. De fleste har fortolket Bentham ifølge den lockeske humanismes motivering om, at grum behandling af dyr degraderer mennesket, og at det synder når det udsætter dyr for smerte.

Benthams dagsaktuelle arvtager Peter Singer hæuder, at Bentham, ved at indføre en gradsforskel i stedet for en kvalitativ forskel mellem dyr og menneske, giver sin lykkemoral, den hedonistiske utilitarisme, større kraft.

Singer opfatter Benthams humanistisk farvede overbevisning om, at alle følelsesvæsner stræber efter at opnå lyst og undgå smerte, som en reaktion på cartesianismen med dens teori om, at dyr er automater. Han hævder også, at Bentham polemiserer mod Kants standpunkt om, at:

dyr ikke er selvbevidste og at de blot er til som et middel for menneskene (Singer (1992), 222). 
Singer deler den individualisme, Benthams utilitaristiske handlingsprincip udtrykker: vi bør handle sådan, at vi tager hensyn til og optimalt tilgodeser alle involverede interesser og præferencer. Ligesom et menneske har et dyr en interesse $i$ at undgå smerte. Vi bør sørge for, at dyrene ikke tilføjes smerte, selv om dette går ud over en del menneskelige interesser. Dyrene deler interesse med menneskene og bør have samme rettigheder. Ifølge Singer er de specifikke forskelle, der sædvanligvis fremhæves for at højne menneskets værdi på bekostning af dyrenes, irrelevante.

Vi tildeler jo ikke et intelligent menneske flere rettigheder end en dåre, heller ikke en snakkelysten flere end en afatiker. Det eneste meningsfulde og moralske kriterium er evnen til at føle lyst og smerte (Singer (1992), 35.)

Kun at tage hensyn til menneskets smerte og ikke dyrenes, er, i Singers øjne, et udtryk for en speciecisme, der er præget af samme vilkårlighed som race- og kønsdiskriminering. Singer forklarer begrebet speciecisme således:

Speciecisme - ordet er ikke tiltalende, men jeg kan ikke tænke mig noget bedre - er en fordom eller attitude af partiskhed til fordel for interesser hos medlemmer af den egne art på bekostning af dem, der tilhører andre arter.

Han finder en enkel analogi med racisme og sexisme.

Racister krænker lighedsprincippet gennem at lægge større vægt på interesser, der tilhører medlemmerne af deres egen race, når deres interesser og andre racers interesser strides. Sexister krænker lighedsprincippet gennem at favorisere deres eget køns interesser. På samme måde lader speciecister deres egen arts interesser veje tungere end andre arters stærke interesser (Singer (1992), 36-9).

I sine tekster giver Singer flere eksempler på den artsundertrykkelse, der forekommer på forskellige områder $\mathrm{i}$ nutidens vesterlandske samfund. Til dem hører, at et stort antal dyr aflives til fordel for videnskabelig forskning og sport, samt at skønheds- og levnedsmiddelindustriens tests af nye produkter skader og dræber dyr. Essensen af hans argumentation er, at

eftersom vi accepterer gyldigheden af de antiracistiske og antisexistiske argumenter, og rationelt set erkender alle interessers ligeværdighed 
(de sortes interesser er lige så vigtige som de hvides, kvinders lige så gyldige som mænds), så bør vi tage yderligere et skridt hen imod at acceptere antispeciecismen (Ibid, 38).

Interesse er et nøgleord for Singer. Men han anvender ordet interesse på to forskellige måder. For det første anvender han "interesse" i betydningen, at lykke kan ligge i et individs interesse. Her knytter han an til Benthams hedonistiske anskuelse af, at alle følelsesvæsner stræber efter at opnå lyst og undgå smerte. Både dyr og mennesker har en interesse $i$ ikke at lide. Singer forstår endda termen interesse som synonym med ønske eller præference. Virkeliggørelsen af individets ønsker og præferencer bliver det mest værdifulde, selv om han helst ikke vil adskille det fra den tilfredsstillelse, man da føler. Denne præferentialistiske tolkning af begrebet interesse tillader Singer at værdigraduere følelsesvæsenerne. De følelsesvæsener, der besidder bevidsthed og har præferencer angående fremtiden, får en større moralsk værdi end dem, der mangler denne evne. Der opstår således en ambivalens, når Singer samtidigt hævder de to utilitaristiske positioner: hedonismen og præferentialismen.

Ifølge hedonisten Singer er dyr og mennesker lige i lidelsen. Evnen til at føle smerte grundlægger respekten for alle følelsesvæsner. Kvalitative biologiske og psykiske forskelle er uden betydning. Det hedonistiske kriterium er ifølge Singer en grundlæggende årsag til at opgive speciecismen.

Præferentialisten Singer

betoner derimod, at evnen til at have ønsker og præferencer angående fremtiden, konstituerer et moralsk subjekt. Specielt tydelig er han i sin artikel "Killing Humans and Killing Animals" i Inquiry's temanummer om dyrenes rettigheder (Singer (1979), 145). Der hævder han, at der behøves yderligere et kriterium for, at noget skulle kunne være at moralsk subjekt, nemlig personligheden [personskapet, o.a.]. Han definerer personligheden, ikke gennem befrugtningen eller fødselen, men gennem fremvæksten af selvbevidsthed (Singer (1996), 74). Det indebærer, at han ikke tager hensyn til potentielle personer, men udelukkende til de allerede eksisterende.

I interviewet foretaget af Henrik Ahlenius i Filosofisk Tidsskrift (3/ 1997) forklarer Singer, at ordet person betegner et væsen, der er bevidst om at leve et liv i tiden. Dette indebærer, at kun selvbevidste væsner kan være moralske subjekter. Hverken de ikke-selvbevidste dyr eller de ikke paradigmatiske mennesker, såsom spædbørn, mentalt handicappede eller senildemente, kan ses som personer. Respekten for disse mennesker, ligesom for ikke-selvbevidste dyr, 
skulle grunde i lidelsens realitet. Som vi senere vil se, reagerer f.eks. Kemp meget stærkt på Singers inhumane definition af personligheden.

Det ser nu ud som om Singer accepterer fornuftskriteriet, som om han tilslutter sig Lockes idé om, at fornuften styrer de moralske beslutninger. Men væsentlige forskelle $\mathrm{i}$ forhold til Locke står tilbage. Som udpræget individualist kan Singer ikke betragte fornuften som en objektiv størrelse. Som utilitarist modsætter han sig desuden, at retten afledes af fornuften.

Man kan hos Singer uddifferentiere følgende kategorier af væsener: menneskelige og ikke-menneskelige personer, samt menneskelige og ikke-menneskelige ikke-personer. Han påstår, at selvbevidste væsener, der har som præference at fortsætte med at leve og som planlægger derefter, eksisterer i noget mere end en øjeblikstilværelse. Derfor bliver tabet, hvis man slår en person ihjel, større, end hvis man slår en ikke-person ihjel. Dør en person, så forsvinder også hans uerstattelige præferencer. En forkortelse af en ikke-persons lykkelige liv er beklageligt, eftersom den totale lykke derved mindskes. Disse ikke-personer er dog erstattelige. Dén lykkereduktion, der sker, når man slår et ikke selvbevidst væsen ihjel, kan afbalanceres ved at give liv til et andet lige så lykkeligt væsen. Dette under forudsætning af, at man tager hensyn til den individuelle interesse $i$ at minimere lidelsen og øge velbefindendet. De fleste dyr, spædbørn samt forstandshandicappede mennesker havner under kategorien ikkepersoner. Singer hævder, at selvmord eller dødshjælp i visse situationer er at foretrække frem for livet. Det er op til den enkelte at afgøre hvornår. Det hele handler om praktiske valg, der må foretages fra tilfælde til tilfælde. Man bør dog holde sig til følgende princip:

Så længe vi husker, at vi bør udvise samme respekt for dyrenes liv som vi udviser for de mennesker, der befinder sig på samme mentale niveau, så havner vi ikke meget ved siden af (Singer (1991), 51).

Singer synes, at de skillelinjer han optegner med henblik på individernes præferencer, går tværs igennem arterne og ikke imellem dem. Med andre ord, at forskellene mellem individer ikke følger grænserne for individernes artstilhørighed. En humanist kan derimod hævde, at Singer afviger fra princippet om, at interessen i ikke at ville lide er en tilstrækkelig grund til at give individer en moralsk status, når han anfører personligheden som differentieringsårsag. $\mathrm{Da}$ det faktisk er mennesker, der i størst udstrækning besidder en selvbevidsthed, skulle man, med Richard Olssons ord, kunne beskylde Singer for i hvert fald 
en partiel speciecisme (Ohlsson (1993)).

Der er meget, der er problematisk i Singers filosofi. Her er nogle eksempler:

(i) Singer vælger evnen til at lide som det moralsk relevante kriterium. Samtidig er det imidlertid blot et indicium på, at væsenerne har præferencer, der bør respekteres.

(ii) Når Singer opretter en distinktion mellem lidelsens og livets værdi, havner han i samme fxlde som den af ham så hårdt kritiserede fornuftsbaserede etik. Singer skelner tydeligt mellem den værdi, et væsen med evnen til at føle smerte og velbehag tildeles, og på den anden side livets værdi, der varierer afhængigt af det mentale niveau, individet lever på. Denne ambivalens er delvist parallel med hans vaklen mellem den hedonistiske utilitarisme og præferentialismen. Hvis man samtidigt tillemper begge disse perspektiver, medfører det, at forskellige væsener behandles ulige. I utilitarismen, som vurderer konsekvenserne af en handling, kan man imidlertid se gennem fingre med dette, eftersom denne behandling er et forsøg på at afstedkomme et lige resultat.

(iii) Singers kritikere lægger også mærke til hans ambivalens $i$ spørgsmålet om naturlige rettigheder. Han tager på den ene side afstand fra disse med dén motivering, at de er fiktive, og at termerne udelukkende er politiske værktøjer, der forenkler virkeligheden, men på den anden side benytter han sig af naturretstraditionens retorik og deler, i det mindste delvist, dens etiske grundlag, nemlig tanken om det fornuftige og selvbevidste menneske.

\section{Tom Regan: For dyrenes naturlige rettigheder.}

Den amerikanske dyreretsteoretiker Tom Regan argumenterer i sin bog The Case for Animal Rights for en annullering af afstanden mellem menneskers og dyrs værdi ud fra naturretsteorien og pligtetikken.

Regan undrer sig over utilitarismens fokusering på følelser og interesser, samtidigt med at de individer, der oppebærer dem, er uvæsentlige i sammenhængen.

For Regan er utilitarismens manglende evne til at tilbyde en principiel fordømmelse af foreteelser, der indebærer en krænkelse af menneskelige og ikke-menneskelige individers ret til liv, helbred samt fysisk og psykisk integritet, uacceptabel. Han reagerer mod, at utilitarismen lader dyrs vel og ve afhænge af en abstrakt opvejning af forskellige interesser, der i særlige tilfælde skulle kunne legitimere, at noget dyreforsøg eller nogen mishandling af dyr gennemføres, hvis konsekvenserne af det er tilstrækkeligt gode i termer af en undvigelse af fremtidig lidelse. 
Godt nok sætter han pris på Singers engagement $i$ at give dyrene en lovmæssig status, men mener samtidig, at hans utilitarisme kun er tilstrækkelig til at argumentere for dyrevelfærd. Kritikkens brod retter Regan imod det faktum, at utilitarismen afviser ukrænkelige rettigheder.

Kritikken af utilitarismen er for ham en måde at markere sin tilknytning til de menneskelige rettigheders liberalisme på. Hans måde at forholde sig til denne tradition på er dog konfliktfyldt. Den indbefatter både tilslutning og tvivl. Denne tilknytning indebærer en kombination af tilegnelse af rettighedsterminologien og samtidig viljen til at give gamle begreber en ny betydning. I første omgang rejser Regan et krav om at udvide rettighedsbegrebet ved at definere dyrene ind i det.

Regan opretter en distinktion mellem grundlæggende eller naturlige rettigheder og ikke-grundlæggende rettigheder. Stillingtagen med hensyn til de sidstnæunte baseres på konsekvensbedømmelsen af en handling. De naturlige rettigheder er derimod forankrede $\mathrm{i}$ individets natur, det vil sige i dets faktiske konstitution. Og de er i sig selv en grund for moralsk pligt, hævder Regan, der i den henseende følger Locke.

Den lockske liberalisme gør sig til talerør for den moralske forpligtelse ud fra en permanent værdi med reference til naturlove. Locke mener, at:
Fornuften som er naturens lov, lærer alle mennesker, der spørger den til råds, at eftersom alle er lige og uafhængige, bør ingen skade nogen anden på liv, helbred, frihed eller ejendom (Locke (1992), 25).

Der findes, mener Locke, en naturlov, der grunder i menneskets fornuft, og der findes naturlige rettigheder med grundlag i denne lov.

For Regan bliver det dog yderst problematisk når Locke hævder, at det at være sin egen ejer er den vigtigste egenskab hos en person eller et moralsk subjekt. Det, han godt kan lide hos Locke, og som han forsvarer over for utilitaristerne, er, at Locke prioriterer en objektiv og uforanderlig værdi grundlagt $\mathrm{i}$ personens konstitution. En værdi der forpligter.

Utilitarismen afviser en forpligtelse, der grunder i selve rettighedens eksistens, som dermed er uafhængig af de gode eller dårlige konsekvenser, en handling medfører.

For Regan er dette en partiel årsag til at tage afstand fra Singer. Men han mener, at Singer opdagede huller i antropocentrismen, da han stillede spørgsmålet om konsekvenser af personlighedens fornuftskriterium for de ikkeparadigmatiske mennesker. Han godtager hverken Lockes fornuftskriterium eller Singers bestemmelse 
af personen som præferencernes indehaver. Deres målestok lever ikke op til kravet om, at alle væsener har en iboende værdi.

Spørgsmålet om, hvem der besidder egenskaber, der befæster grundlæggende moralske rettigheder, besvarer Regan ved at foreslå en universalistisk løsning, der overskrider artsgrænserne. Men hans tekster viser, at han ikke er konsekvent $i$ sin definition af det moralske subjekt, det såkaldte livssubjekt. Han sætter ikke altid standarden for indehavelse af rettigheder på samme niveau. Når han hævder, at det, der gør både menneskelige og ikkemenneskelige dyr til livssubjekter, er en bevidsthed og en psykologisk identitet over tid, så sætter han vilkårene for rettighedsindehavelse sådan, at kun pattedyr henregnes til livssubjekterne (Regan (1998)). I en anden sammenhæng formulerer han betydeligt svagere vilkår. Han har efter eget udsagn indset, at visse dyr kan have et oplevelsesmæssigt liv, men at de mangler bevidsthed om verden og om sig selv. Derfor er en evne til positive og negative oplevelser et tilstrækkeligt vilkår til at være livssubjekt. I hans artikel i Inquiry's temanummer om dyrenes rettigheder fremkommer det biocentriske budskab mere tydeligt.

På en måde er alle de pågældende mennesker, inklusive de svært mentalt svækkede, ikke kun i live, men er subjekter for et liv, der i sig selv har værdi for det individ, hvis liv det er (Regan (1979, 208).

Regan mener altså, at alle - bortset fra de uigenkaldeligt hjernedøde - der har et liv som er mere eller mindre værdifuldt for dem, også har en iboende værdi og besidder naturlige rettigheder. Men han indrømmer, at der findes forskelle mellem de paradigmatiske mennesker, der styrer deres eget liv, og alle de andre som har men ikke bevidst lever et liv. Han medgiver, at de normale mennesker har udviklet evnen til at tænke rationelt og handle ansvarligt. De taler et symbolsk sprog, og de er i stand til at forstå deres livssituation og sig selv.

Men ifølge Regan konstituerer de ovennævinte egenskaber ikke det moralske subjekt. Derfor sanktioneres ingen eksploitering eller undertrykkelse af de marginale individer. Som livssubjekt kan en indehaver af naturlige rettigheder per definition ikke behandles blot som middel til opnåelse af normale menneskers mål. I den logiske konsekvens' navn bør altså også dyrene tilkendes naturlige rettigheder, da de ikke på nogen væsentlig måde adskiller sig fra de marginale mennesker. Samtidig foretager Regan en distinktion mellem moralske agenter og patienter. Agenterne er de voksne mennesker, der besidder fornuftsog følelsesevner. Patienterne er de marginale mennesker og dyrene. Agenterne har en pligt til at handle 
moralsk over for hinanden og over for de moralske patienter, der er genstand for omsorg. Kun agenter skylder at respektere alles rettigheder. Men dette, hævder Regan, påvirker på ingen måde den moralske status hos dyr som rettighedsindehavere. Regan mener at foretage en rimelig omfortolkning af naturretten, så den udgør et forsvar for dyrenes rettigheder, samtidig med at de marginale mennesker beholder deres position som moralsk agtelsesværdige. Man kan dog hævde, at det trods alt ikke lykkes for Regan at slippe afsted med at rangordne væsenerne. Først fjerner han fornuftskriteriet, for at kunne inkludere de marginale i det moralske fællesskab, men i næste omgang genindfører han samme fornuftskriterium med det resultat, at et værdihierarki trods alt opretholdes.

Ifølge Regans fortolkning skulle kravet om dyrenes og naturens rettigheder være en logisk følge af den lockeske liberalisme. Regan går dog ud fra de marginale menneskers position, hvilket Locke ikke gør. Det er netop Regans syn på de naturlige rettigheders bærere, der udgør et kvalitativt brud med den lockeske liberalisme. Præcis på dette sted ser humanisten et svagt punkt hos Regan og spørger: Er det ikke underligt at hævde, at det er netop den egenskab at være livssubjekt, der giver moralske rettigheder, når det åbenbart ikke er tilstrækkeligt på grund af det yderligere vilkår, at der skal findes moralske agenter? Tanken om en historisk udvidelse af kredsen af rettighedsindehavere, der hører til standarden inden for dyreretsteorierne, er af stor betydning for Regan. Han sammenkobler dette med de naturlige rettigheders liberalisme. Også Singer har et billede af en etisk kreds, der i takt med demokratiets fremskridt lige så stille udvider sig. Den amerikanske økologiorienterede idéhistoriker Roderic Nash fremfører i darwinismens spor den tese, at moralen gennemgår en evolution, $o g$ at dette er noget iboende $i$ den naturretslige liberalisme. Hans påstand skulle i denne sammenhæng styrke Regans argumentation. Nash mener, ligesom Regan, at den angloamerikanske liberalismes historie er et eksempel på, at grænsen for erkendelse af rettighederne til stadighed udvides. Han hævder, at kravet om at erkende dyrenes og naturens rettigheder bør ses:

Ikke så meget som et oprør imod traditionelle amerikanske idealer, som en udvidelse og ny anvendelse af dem ${ }^{1}$.

Ud fra Nash's perspektiv skulle miljø- og veganbevægelsers krav kunne udledes af den amerikanske kulturs naturretslige fundament, hvor menneskelige rettigheder forstås som naturlige rettigheder. 
Humanisterne imødegår udfordringen

Luc Ferry, Peter Kemp og Ingemar Nordin er bevidste om de problemer, nutidens humanister står overfor, f.eks. at den traditionelle antropocentriske etik ikke øver retfærdighed over for vor tids menneskers følelse for naturen. Deres holdning medfører også en vilje til at genfortolke humanismens sætninger sådan, at de skal rumme en seriøs hensyntagen til bioetik og miljøspørgsmål. De tager Singers og Regans kritik af humanismen meget alvorligt. Men hvordan besvarer de den?

\section{Ingemar Nordin: Dyr er ikke mennesker}

Mens miljødebatten i Sverige i højeste grad har tilpasset sig den parlamentariske kulturs spilleregler, så er debatten om dyrenes rettigheder endnu ikke inkorporeret $\mathrm{i}$ den institutionelle politik. Dyreretsspørgsmålene udgør et følsomt emne i den offentlige samtale, der blandt andet føres i massemedier, på universiteter og inden for veganbevægelsen. Samtidig med, at veganbevægelsen i de seneste år har intensiveret sine handlinger, så er også kritikken blevet optrappet. De fleste kritiserer bevægelsen for dyrenes ret for at være udemokratisk og udenomsparlamentarisk.
Nordins kritik er derimod rettet imod dyreretsfilosoffer, der tilbyder legitimering af dyreretsaktivismen. Han gennemfører den $i$ en bog med den sigende titel Djur är inte människor. Allerede i indledningen påpeger Nordin, at Singers og Regans

grundproblem er at deres affærdigelse af en moralsk distinktion mellem mennesker og dyr er vilkårlig og ikke i tilstrækkelig grad tager menneskets unikke position som moralsk og civilisatorisk væsen i betragtning (Nordin (1997), 3).

Til en begyndelse ræsonnerer Nordin over Singers intentioner $\mathrm{om}$, på en utilitaristisk grund, dels at mindske lidelsen i verden og dels, på samme grund, at skabe et alternativ til den speciecistiske tænkning. Nordin medgiver, at spørgsmålet om dyrevelfærd slet ikke er ubetydeligt $\mathrm{i}$ vores højindustrielle verden. Singer peger uden tvivl på åbenbare misforhold, der burde afhjælpes. Men Singer er ifølge Nordin for nonchalant angående mange menneskers besvær med at leve vegetarisk. Derfor retter han en række spørgsmål mod Singer:

Hvad skulle vi gøre med dem, der ville få det dårligt af en helt vegetarisk diæt? Er det rimeligt, at hvide middelklasseveganere 
fra en rig vesterlandsk kultur påtvinger eskimoer, indianere og andre gamle kulturfolk deres livsstil? Hvor velbegrundet er påstanden om, at vi kan klare os uden plagsomme dyreforsøg i den medicinske forskning? Hvor mange menneskelige interesser, hvor megen rigdom, helbred og livskvalitet måtte ofres for at Singers vision om det gode samfund kunne virkeliggøres? (Ibid, 7-8).

Kritikkens brod retter Nordin imod det singerske alternativ til den speciecistiske tænkning, en utilitaristisk idé om den moralske og juridiske lighed mellem mennesker og dyr.

Kan utilitarismen være en holdbar grund til at affærdige den moralsk relevante distinktion mellem menneske og dyr, spørger Nordin retorisk. Sit nej-svar forankrer han i kritikken af utilitarismens anvendelighed og rigtighed, der også er Singers hovedproblem. Først gransker Nordin kritisk ligheds- og optimeringsprincippet. Lighedsprincippet siger, at vi bør sammenligne og opveje disse interesser $\mathrm{i}$ en kollektiv mængde og siden forsøge at få et udfald hvor vi optimerer tilfredsstillelsen af interesserne. Disse principper synes tillokkende $i$ deres abstrakte udformning, men viser sig at have uacceptable praktiske implikationer ved konkret anvendelse. F.eks. at man ofrer individerne $i$ den hensigt at få et optimalt udfald på den samlede mængde af lystfølelse $i$ verden. Nordin er utryg ved utilitarismens fokusering på det totale resultat og på behovet for at udføre nyttekalkulerne, ligesom fraværet af handlingens agent kan lede til, at visse individer på en alt for uproblematisk måde kan ofres for det større gode. Der er noget fordækt ved en etisk teori, der påbyder handlinger som synes at stride imod vores moralske intuition om, hvad der er en god handling, påstår Nordin bestemt. I Regans tilfælde er det ikke valget af etisk grundlag for hans krav om et udvidet etisk fællesskab, Nordin afviser. Derimod reagerer Nordin stærkt imod at Regan med udgangspunkt i naturretslig tradition tilskriver samme moralske status som et livssubjekt med ukrænkelige rettigheder til dyr som til mennesker.

Nordin rejser generelle indvendinger, der angår både Regan, Singer og dyreretsteorien iøvrigt. Han er kritisk imod den påstand, at sociale rettigheder gennem historien bestandigt udvides (til at inkludere kvinder, børn og slaver), og at det blot er logisk også at inkludere dyr i omsorgskredsen og rettighedernes domæne. Nordin ser ingen logisk nødvendighed $i$ at behandle alle grupper lige, alene fordi de har visse fælles egenskaber. Det handler om forskellige slags undertrykkelse og 
forskellige egenskaber der udløste det, og om forskellige mennesker der udøvede det (Nordin (1997), 30). Nordin påpeger med rette, at denne udvidelseslogik ikke har nogen naturlig slutning. Man kan fortsætte vilkårligt længe og inkludere f.eks. insekter, bakterier og virus. Hans konklusion er, at dyreretsteorierne døjer med deres egne grænsedragningsproblemer. Den anden hovedindvending gælder dyreretsteoretikernes tese om, at det er umuligt at finde et moralsk relevant kendetegn der adskiller alle menneskelige væsner fra alle medlemmer af andre arter. Deres rigide fastholdelse af analogien mellem dyr, børn, mentalt syge og senildemente afviser han bestemt.

Ifølge Nordin ligestiller Singer og Regan mennesker med dyr af ganske vilkårlige årsager. Han undrer sig f.eks. over vilkårligheden i Singers valg af den for mennesker og dyr fælles interesse $i$ at undgå smerte som en så central moralsk faktor. Hvis Singer havde valgt andre vigtige interesser, såsom reproduktion eller driften mod at skaffe næring, så ville domænet for hans filosofi have udvidet sig radikalt. På samme måde sætter Nordin spørgsmålstegn ved, om den af Regan udvalgte egenskab, at være livssubjekt, kan være tilstrækkelig til at have rettigheder. Uden liv findes der ingen bevidsthed, følelser, rettigheder. Hvorfor da ikke påstå, at alt liv har rettigheder og ikke bare livssubjekter.
Man mærker hos Nordin en ambition om at forene en betragtning om mennesket som et primært biologisk væsen med et ikke-cartesiansk humanistisk menneskesyn. Darwins udviklingsteori og oplysningshumanismen er Nordins vigtigste holdepunkter. At det sidste udgør et etisk referencepunkt hos Nordin anskueliggøres, når han f.eks. viser behovet for referencer til det universelle i mennesket og forsvarer menneskeværdiens selvfølgelighed. Nordin fremviser også en civilisatorisk optimisme, troen på at mennesket hele tiden successivt går mod en højere frihed og en højere fornuft. Og hans tillid til videnskaben er også iøjnefaldende. I overensstemmelse med dette reagerer Nordin positivt på, at Singers argumentation for dyrenes frigørelse ikke er nogen tilbagetil-naturen-filosofi. Tværtimod forudsætter Singer ifølge Nordin

"et moderne, sofistikeret og nogenlunde rigt samfund, hvor vi mennesker uden selv at uddø eller lide alt for meget kan erstatte køddiæten med en ernæringsrigtig vegetarisk kost (Ibid, 30)".

Darwins teori har givet anledning til forskellige fortolkningsmuligheder. Singer følger den fortolkningslinje, at $i$ og med Darwins opdagelse af, at mennesket nedstammer fra dyrene, er menneskets særstatus i 
verden blevet bragt i tvivl. Ifølge Singer underminerede Darwin troværdigheden i den kristne moraldoktrin om menneskelivets hellighed og gjorde dualismen mellem menneske og dyr ugyldig.

I modsætning til dette har Darwins idé om en naturlig selektion i naturen været til hjælp for Nordin i underbyggelsen af et antropocentrisk perspektiv. Han henviser til Darwin, når han fremholder, at menneskets intellektuelle evner er fremkommet gennem naturlig udvælgelse. $\mathrm{Og}$ han følger Darwins udviklingsteori, når han forklarer menneskets særstilling. Gennem den naturlige udvælgelse har mennesket udviklet sin bevidsthed, der gør det unikt blandt dyrene. Bevidstheden gav mennesket et forspring frem for andre dyrearter $\mathrm{i}$ spørgsmålet om overlevelse. Men vigtigere er, at mennesket har kunnet skabe en egen civilisatorisk udvikling ved siden af den biologiske. Nordin mener, at med fornuftsegenskaberne følger også evnen til at vælge frit og gøre moralske overvejelser. Godt og ondt, ret og uret er uvedkommende ting $i$ naturen hinsides den menneskelige sfære. Den dimension hører i stedet sammen med mennesket og dets evne til at bedømme moralsk og til at handle fornuftigt. Vist findes der væsener, der har en slags bevidsthed og interesse $i$ at undgå smerte, men evnen til at tillægge dette moralske aspekter, findes kun hos mennesket ${ }^{2}$.
Det er ifølge Nordin snæversynet af Singer og Regan at bortræsonnere fornuftsegenskaberne som centrale for moralske værdier og moralsk handlen. Måske beror det på deres fejltagelse: at betragte børn og udviklingshæmmede som jævnbyrdige med chimpanser og grise. Følgelig må de vælge mellem enten at regne normale voksne for fundamentalt set mere værdifulde end børn og forstandshandicappede, eller at vælge en egenskab, der placerer alle mennesker og dyr på omtrent samme niveau. Singers og Regans første alternativ er, at kun de rationelle voksne mennesker er moralske subjekter. (I overensstemmelse med dette skulle imidlertid argumentet om, at mennesket er unikt på grund af sin fornuft, kunne berettige udførelsen af eksperimenter på eller slagtning af børn, forstandshandicappede og senildemente.) Det andet alternativ fører til,
at valget af en alternativ fundamental egenskab bliver ganske vilkårlig og ad hoc, samt at man må afvise fornuftsegenskaber som noget relativt uvæsentligt $\mathrm{i}$ sammenhængen (Ibid, 48).

Nordin opfatter begge alternativer som menneskefjendske. Nordin mener imidlertid, at hvis vi respekterer fornuftsfunktionen som sådan, så respekterer vi rimeligvis 
alle individer der bærer den, selv om fornuften ikke er færdigudviklet eller er sat ud af funktion gennem sygdom eller skade. Alle mennesker har en hjerne, hvis biologiske funktion er at udvikle fornuft. Et barn har f.eks. en biologisk funktion, der med tiden skal udvikle fornuft, hvilket en gris eller en chimpanse ikke har. Selv en forstandshandicappet eller senildement har en potentiel fornuft, der ikke er udviklet eller som er skadet. Der er i Nordins øjne en tydelig forskel mellem at mangle en funktion og at have et skadet organ.

For Nordin er det selvfølgeligt, at mennesket er det, der sætter moralske værdier.

Den menneskelige moral er noget unikt som dyrene ikke har. Dyrene har ikke engang mulighed for at udvikle den. Deres sociale mønster bygger på forskellige naturlige regler, der ikke har med moral at gøre. Men Nordin hæuder, at han blot mener, at der findes en moralsk forskel mellem dyr og mennesker, ikke at dyr mangler moralsk værdi.

Nordins humanistiske holdning handler om ikke blot at bekymre sig om dyrene for menneskets egen skyld, alene af hensyn til menneskets helbred eller børnenes fremtid, men også om at begynde at se dyrene og naturen som et område for menneskeligt ansvar. Nordin betoner det vigtige i, at man viser hensyn til dyrene, men at man ikke lader afstanden mellem menneskenes og dyrenes værdi ophæve, fordi dyrene mangler det biologiske grundlag for ukrænkelige rettigheder. Mennesket er det eneste væsen, der kan bekymre sig om, hvordan dyr skal behandles ud fra en etisk synsvinkel. Det gør mennesket moralsk unikt og forpligter det til at tage hånd om dyrene. Hensynet til dyrene motiverer han således ud fra uligheden mellem mennesker og dyr. Han mener, at menneskets fornuft giver det et begreb om ansvaret for den natur det lever $\mathrm{i}$.

\section{Peter Kemp: udvid idéen om den menneskelige persons u- krænkelighed til en idé om den levende verdens ukrænkelighed}

Kemp er en mangesidig tænker med forankring $\mathrm{i}$ en række filosofiske traditioner og hos de store klassikere som Aristoteles og Kant, ligesom hos vor tids filosoffer som Ricoeur og Lévinas. I Norden anerkender man ham som en udmærket indfører i kontinental filosofi. I 80erne og 90erne var det teknologi og etik der fangede hans interesse, hvilket er tydeligt i hans bog Det uerstattelige. Denne bog er vores hovedreference, idet vi undersøger hvordan han håndterer miljø- og bioetikkens udfordring af den moderne humanisme. Man slås af hans stærke tro på at kunne udforme en humanisme med naturhensyn, og af hans vilje til at forstå de brændende etiske spørgsmål i det samtidige 
samfund. Han formulerer selv relevante spørgsmål som f.eks.

Hvordan vi filosofisk
set kan forestille os bio-
teknikkens grundlag i sin
fulde udstrækning: betyder
etikkens udvidelse til at
være en etik for hele den
levende verden, at vi nu kan
og må basere personetikken
på etikken for den levende
natur og følgelig må aflede
menneskets værdighed fra
en idé om livets værdighed,
eller måske tilmed fra en
idé om en værdighed der
gælder hele det økologiske
system, i hvilket vi indgår
som personer? Eller betyder
denne udvidelse at personen
stadig udgør grundlaget?
(Kemp (1991), 177).

Vist er kritikken af Singers utilitaristiske argumenter for hensyn og respekt for dyrene et led i Kemps søgen efter svar på disse spørgsmål. Han anerkender Singers kamp for "dyrenes frigørelse" og argumentationen mod cartesianere, der vil holde dyrene uden for den egentlige etiks område. Han mener samtidig, at Singers etik for dyrene hviler på et filosofisk set meget diskutabel utilitaristisk grundlag. Med Singer i bagtanken fastslår Kemp, at bioetikken ikke kan bygge på en ren sympati eller på en fælles interesse med nogle dyr. Han bedømmer det singerske lighedsprincip, der siger at vi bør tage lige hensyn til alle involverede individers interesser, til at være utilstrækkeligt til at fungere som grundlag for hensyn og respekt over for menneskelige og ikkemenneskelige individer. Hævder man, at menneskets lighed med dyrene er en tilstrækkelig grund til ansvarlighed over for dem, så underminerer man det ansvar man vil forsvare, påstår han bestemt.

Kemp betoner i stedet uligheden mellem menneske og dyr.

Det er snarere uligheden end ligheden mellem menneske og dyr, der pålægger mennesket forpligtelser over for dyret (Ibid, 181)

står der i Det uerstattelige. Men hvad består uligheden i? Kemp mener, at
Mennesket er (...) radikalt forskelligt fra dyrene gennem dets erfaring af virkelig tid, ud over det umiddelbare øjeblik, og dermed dets erfaring af muligheden for at kunne lide, hvilket er noget andet end at føle smerte og at være frustreret (Ibid, 180).

Mennesket har evnen til at danne sig en narrativ vision af det gode i livet, og det er faktisk ene om at have denne narrative kapacitet. Evnen til at skabe sig en i tiden udstrakt opfattelse om, hvad det gode i livet er, er tæt knyttet sammen med et 
ansvarsbegreb. Dette ansvarsbegreb forudsætter, at mennesket må være nærværende i den verden, det lever i. Også menneskets evne til helhedssyn på naturen påbyder det et ansvar for naturen. Dyrene har ikke ansvar for noget som helst, hverken for deres art eller for naturen. Kun mennesket kan forstå sig selv som ansvarligt for livet. Kemp mener, at det narrative træk i den vestlige kultur ophøjer samtidig med at det forpligter.

At mennesket er et følelsesvæsen og at ethvert individ er uerstatteligt er én af Kemps grundteser. I Lévinas' spor henlægger Kemp forudsætningen for menneskets ansvar for livet til dets kropslighed og følelsesevne.

Kemps idéer om menneskets værdighed og uerstattelighed har deres grundlag i Kants tanker om dets moralske autonomi, der, i overensstemmelse med Lévinas, først bekræftes gennem et møde med den Anden. Udfra henvisningen til Lévinas forklarer Kemp, at kun $\mathrm{i}$ mødet med den Anden som den unikke person stilles vi til ansvar for det uerstattelige og derfor ukrænkelige. Vi kan ikke møde den levende natur på samme måde som vi møder en anden person, der lægger sit liv i vore hænder.

Dette indebærer, at uanset om naturen som helhed er lige så unik og uerstattelig som den anden person, så er det ud fra det nære forhold til den Anden, vi kan tænke os ansvaret $\mathrm{i}$ tid og rum og dermed ansvaret for naturen som helhed i sin rumlighed og tidslighed (Ibid, 180).

Som citatet viser, understreger Kemp, at respekten for livet må grunde i det menneskelige livs ukrænkelighed, hvilket indbegriber både personen og dennes kropslighed. Gennem kropsligheden er mennesket delagtigt i naturen. Personens rødder strækker sig så at sige derud. Vi ved, at den menneskelige person har sit livs rødder $\mathrm{i}$ udviklingen af et foster og en krop, og dermed i udviklingen i naturens verden, konstaterer Kemp. Af respekten for personens kropslighed følger også respekt for livet før selvbevidstheden og dermed for potentielle personer. Både de aktuelle og de potentielle personer er uerstattelige. Her udgør Singers inhumane personopfattelse, der bl.a. diskriminerer på basis af bevidsthedsniveauer, et negativt referencesystem. Kemp tager afstand fra Singers spørgen til det traditionelle syn på menneskelivets hellighed, og fra nægtelsen af enhver idé om respekt for den potentielle person. Han mener at:

uden en udvidelse af respekten for menneskelivet fra at gælde for den fuldt udviklede person til også at gælde for den potentielle person, der netop er født, ja selv for tiden før fødslen, (omend i aftagende grad), 
har man ingen etisk gyldig grund til at undgå abort (i det mindste til en vis grænse) og til ikke at dræbe spæd- og småbørn (Ibid, 173).

Ved at udstrække ansvaret til at gælde for potentielle personer, lader Kemp det også omfatte kommende generationer. Ansvarets rumlige dimension, dets miljøaspekter, muliggøres også af den ukrænkelige persons biologiske forankring. Kemp hævder, at

Hensynet til naturen forstås og hævdes også som hensyn til naturens eget liv, gennem en udstrækning eller udvidelse af idéen om den menneskelige persons ukrænkelighed, sådan at den bliver en idé om hele den levende verdens ukrænkelighed (Ibid, 180).

Kemp vil hermed sige, at den menneskelige værdighed ikke kun udstrækker sig til det specifikt menneskelige men også er applicérbar på naturens verden. Idéen om det ukrænkelige menneske forbliver etikkens grundlag, selv om den ikke kun er en etik for mennesker men for hele den levende natur. Han slutter, at "etikken må således være antropocentrisk, eller snarere antropo-centrifugal" (Ibid, 180-1), det vil sige at den må udgå fra respekten for mennesket. Kemp plæderer for en etik, der ophæver nærhedsetikkens begrænsning, (der fra Aristoteles, Kristus og Kant, til Sartre og Lévinas, bibeholder en indskrænket forestilling om hensyn kun til menneskene, ikke til dyrene eller den øvrige natur), uden af den årsag at skabe en afstandsetik.

Kemp refererer her til en anden inspirationskilde, nemlig dybdeøkologen Hans Jonas, der mener at nærhedssfæren overskygges af et voksende område af kollektiv handlen. I dette er den handlende, handlingen og dennes virkning ikke længere de samme som i nærhedssfæren, et område, der gennem dets kræfters umådelighed påtvinger etikken en ny, aldrig før anet ansvarsdimension. Jonas hævder også, at etikken ikke tidligere var tvunget til at tage hensyn til dette menneskelige livs globale vilkår og slægtens fjerne fremtid, eller til videnskaben. At dette er med i spillet idag, kræver et nyt syn på rettigheder og pligter.

Men ifølge Kemp er Jonas' forslag til en ny etik ikke tilstrækkeligt. De må kompletteres af en nærhedsetik, og særligt af Lévinas' tanker om den Anden. Men også Lévinas' nærhedsetik må korrigeres, og nu med hjxlp fra Jonas, dog ikke fra hans afstandsetik men fra hans ansvarsetik.

Både Lévinas' og Jonas' teorier går ud på, at vores eksistens $i$ bund og grund må være etisk. Etikken skal jo sige os, mener Kemp, hvilket liv der er det bedst mulige at leve. Det turde også være det vigtigste filosofiske spørgsmål. 
Luc Ferrys humanistisk-demokratiske alternativ

Den franske filosof Luc Ferry tilhører en generation af franske filosoffer, der vægrer sig imod at give efter for alle de postmoderne alternativer til humanismen, der med hans egne ord

voldfører sig på mangfoldigheden $i$ arven fra oplysningen, der vanskeligt lader sig beskrive som udelukkende instrumentel eller teknisk fornuft (Ferry (1997), 81).

Ifølge sin egen forsikring har Ferry $\mathrm{i}$ alle de bøger, han har skrevet $\mathrm{i}$ de seneste 15 år, forsøgt at udvikle principper for en ikke-metafysisk humanisme. I 1992 publicerede han sin mangefacetterede bog med titlen Nowvel ordre écologique (i Sverige udkom bogen i 1997 med titlen Den nya ekologiska världsordningen). I bogen, der er en del af hans ovennævnte projekt, gør han klart, hvad der står på spil i konflikten mellem økologien og humanismen. Særlig opmærksomhed tilegner Ferry de filosoffer, der udgør
På det filosofiske område ytrer den sig ved, at økologiorienterede filosoffer forsøger at forandre definitionen af det moralske subjekt. De forsøger at gennemføre en periferisering af mennesket. Ferry mener dog, at dyreretsteoretikerne Singer og Regan, trods deres afstandtagen fra det humanistiske menneskesyn, ikke forlader det antropocentriske plan helt og fuldt. Derimod forsøger samtlige dybdeøkologer at fuldbyrde naturaliseringen af mennesket, og at gøre det til en del af den holistiske helhed. Kritikken af dybdeøkologien leverer han bedst selv:
Ved at definere naturen som retssubjekt ophøjer dybdeøkologerne biosfæren eller kosmos til en etisk model for menneskene. Som om verdensordenen var god i sig selv, og at alt ondt kom fra den selviske menneskeslægt (Ibid, 168).

Ud fra humanisten Ferrys synsvinkel udledes dybdeøkologiens etiske imperativ ud fra en sakraliseret natur ved hjælp af økologividenskaben. Sakraliseringen af naturen er et radikalt brud med den verdslighed, den moderne demokratiske kultur er kendetegnet ved. Ferry hævder, at politikkens normer og vurderinger idag stort set er frigjort fra den teologiske verden, men at dybdeøkologien trods det knytter sig til romantiske, vitalistiske og endda 
panteistiske traditioner. For Ferry derimod er naturen adskilt fra det menneskelige subjekt. Derfor mener han, at det er umuligt at udlede en moral af den. Loven foreskrives ikke udefra, men er iboende i det enkelte individ. Med andre ord må moralen udledes ud fra individets frie vilje. Det er denne autenticitetsetik, dybdeøkologien benægter, mener Ferry.

Med kravet om dekonstruktion af humanismen følger også kravet om dets politiske modsvar, den liberal-demokratiske verden. Ferry hævder, at dyreretsteorierne, ved at betragte dyrene som juridiske personer, forsvarer gyldigheden af det hidtil uomtvistelige grundlag for de vurderinger (der formuleres i termer af menneskeværd, naturret og samfundspagt), et vesterlandsk lovsystem hviler på. I og med dette bidrager de til at svække det vestlige demokrati. Dybdeøkologien går et skridt længere og forkaster den type af demokrati, der er en arv fra menn eskerettighedserklæringen og som er indskrevet $i$ vores moderne samfund. Den tilbyder et forjættende utopisk mål: det økologisk perfekte samfund. Dermed åbnes nye horisonter for det militante engagement. Det, der ifølge Ferry gør dybdeøkologien så farlig, er den gode jordbund, den udgør for en totalitær magtudøvelse, og for en total mistro til alt, der har med udviklingen at gøre.

Ferrys kritik er som sagt todimensionel. Den retter sig både imod dyreretsteorierne og imod dybdeøkologien. Men med hensyn til den afgrænsning af emnet, jeg foretog, vil jeg fokusere på Ferrys diskussion af dyreretsteorierne.

Ferry udskiller tre forskellige filosofiske standpunkter i forhold til spørgsmålet om dyrenes rettigheder. Det første mødte vi i cartesianismen, der ifølge Ferry udgør den fuldendte model for en antropocentrisme, der tildeler mennesket alle rettigheder og ingen til naturen, heller ikke til dyrene. Utilitarismen er det andet standpunkt. Det tredje udgår fra en positiv fortolkning af Kant og Rousseau, hvor dualismen mellem menneske og natur ikke baseres på naturlove, men på friheden. Det er ud fra dette sidstnævnte standpunkt, Ferry kritiserer utilitarismen.

Ferry mener, at Singer fejlagtigt placerer den rousseauskkantianske frihedsbaserede etik hos den cartesianske fornuftsbaserede etik. Han mener, at Singer misforstår Rousseau og Kant. For dem stod det klart, at det ikke er egenskaber som sprog, lidelse eller fornuft, der gør mennesket til et moralsk væsen, men friheden. Eller på et andet niveau den gode vilje, dvs. evnen til at handle på en uselvisk, interesseløs måde.

Ferry medgiver, at der på de egenskabers niveau, utilitaristerne gjorde opmærksom på, findes en vis kontinuitet,

men når det gælder friheden, åbner der sig et svælg mellem dyr og mennesker (Ibid, 73). 
Den tolkning af den kantianske frihed, Ferry giver, vises af hans ord:

Menneskets humanitas består i friheden, i det faktum at det ikke har nogen definition, at dets natur er ikke at have nogen natur, men at besidde evnen til at løsgøre sig fra enhver bås, man vil lukke det inde i. Eller snarere, dets essens er ikke at have nogen essens (Ibid, 35).

Af citatet fremgår det, at Ferrys tolkning af den kantianske frihed får en markant eksistentialistisk karakter. Det kantianske synspunkt, at vi er fornuftige viljer og at menneskets essens er lig med dets moralske natur, får her en udlægning $\mathrm{i}$ sartreansk ånd.

Ferrys menneskebillede bygger på den rousseausk-kantianske antropologi.

Mennesket er først og fremmest et antinaturligt væsen. Det er det, der specifikt adskiller det fra andre levende væsner, deriblandt dyrene som det ligner mest. Det er på grund af denne antinatur, mennesket undgår naturens kredsløb, idet det træder ind i kulturen og den moralske sfære, hvilket forudsætter en væren-for-loven i kontrast til en væren-for-naturen (Ibid, 29).

Dette i kombination med et personbegreb inspireret af Sartre: "Mennesket må for at være autentisk være tro mod sin essens (som er ikke at have nogen essens), destruere alt indhold der risikerer at bestemme det."

Det eksistentialistiske motiv og det negativt-dialektiske moment er også tydeligt i Ferrys filosoferen om politikken og kulturen. Han mener, at friheden manifesteres gennem menneskets bestandige løsrivelse fra dets biologiske bestemmelse og gennem skabelsen af kulturen. Denne frihed antager form af et permanent opbrud. Han betoner at friheden, løsrivelsen, og opbruddet er blevet hyldet $\mathrm{i}$ den demokratisk-liberale kultur, i hvert fald siden den Franske Revolution. Uden friheden ville historien, den specifikt menneskelige opfattelse af tidens udstrækning, reduceres til etologi.

Ferry begrunder altså sin etik $i$ friheden (Rousseau, Kant) og ikke i interesser (utilitarisme) eller i fornuften (Descartes, Locke). Rousseau og Kant mente, at menneskets overordnede mål var friheden, og ikke i første omgang at beskytte nogens eller nogets naturlige rettigheder. Denne tænkning burde også, ifølge de to filosoffer være kommet til udtryk i det oplyste samfunds juridiske system. Friheden er blevet både målet for den moralskpolitiske handlen og grundlaget for retssystemet $i$ den liberaldemokratiske tradition, hævder Ferry bestemt. 
Det er et antropocentrisk standpunkt, men omfatter bl.a. gennem dets altruisme, en forpligtelse til ikke at udsætte dyr for unødig lidelse. For Ferry er altruismen et antinaturligt handlingsprincip, der siger, at mennesket bør handle interesseløst efter de universelle, almengyldige mål i modsætning til de egoistiske mål, der kun angår den enkelte.

Ferry spørger: Hvorfor skal vi føle os forpligtede over for dyrene? Hvorfor fremkalder de modstridende følelser i os? Forklaringen ligger $i$, at dyret er dobbelttydigt $\mathrm{i}$ den betydning, at det på den ene side er naturbundet, men ikke reduceres til en automat i Descartes' forstand, eftersom det på den anden side har evnen til at handle efter forestillingen om mål. Ferry hævder, at det er på grund af denne evne til at handle målrettet, at dyret, analogon til et frit væsen, er forbundet med os. Kants tanke om, at dyret er en analog til det menneskelige, er et udgangspunkt for Ferrys ræsonnement om årsagerne til respekt for dyrene. Denne analogirelation gør, at vi, gennem at blive opmærksomme på de menneskelige træk ved dyrene, og gennem at respektere dem, også viser respekt for mennesket.

Ferry mener, at trods de forskellige filosofiske argumenter, Regan og Singer fremfører, så opfatter de i grunden dyrene som værdige til respekt $i$ og for sig. Forskellene mellem dem er uvedkommende. Men Ferry overser, at hans kritik af Singer på et vigtigt punkt stemmer overens med Regans. Ligesom Regan bestrider Ferry ikke selve argumentationens indhold hos Singer (dyrene har interesser), men dens grundpræmis (interessen grundlægger retten), af hvilket følger at lovene er til for at beskytte vores interesser og dermed vores rettigheder. Ferrys spørgsmål er, hvordan man kan bebrejde Singer, at han drager konsekvenserne af en præmis, der i høj grad er accepteret som gyldig, i hvert fald blandt

de retsopfattelser, der dominerer $\mathrm{i}$ de angelsaksiske lande, hvor retssystemet opfattes som et system til beskyttelse af interesser (Ibid, 66).

Ferrys spørgen til, om Singer virkelig tager rendyrket afstand fra den naturretslige tradition, synes trods alt at være på sin plads, hvis man betænker at Singer faktisk scorer point på at henvise til tidligere emancipatoriske hændelser, (f.eks. Mary Wollstonecrafts kvindeemancipatoriske bestræbelser, eller abolitionisternes kamp mod slaveriet i USA) og på at drage paralleller til kravet om dyrenes frigørelse. Så selv om Singer ikke som Regan anvender en rettighedsterminologi, vil han ifølge Ferry vise

at dyrerettighederne i umiddelbar forlængelse føl- 
ger efter de menneskelige rettigheder, efter den rationelle og demokratiske afstandtagen fra racisme og sexisme (Ibid, 71).

Det skulle betyde, at de antispeciecistiske argumenter har samme gyldighed som antiracistiske og antisexistiske argumenter.

Kan man da, sådan som Ferry synes at mene, indlejre de dyreretsteoretiske synspunkter $i$ de menneskelige rettigheders liberalisme? Er det rimeligt at placere Singer i den liberale naturretslige tradition sådan som Ferry gør? Hos Singer bemærker man både en afstandtagen fra begrebet naturlige rettigheder og en tilegnelse af rettighedsretorikken i den politiske liberalisme. Dér har begrebet naturlige rettigheder været centralt siden Locke. Dan Egonsson hævder tilmed, at Singer bygger sin personopfattelse på Locke (Egonsson (1993), 3). Man bør dog ikke overse, at trods ligheden i spørgsmålet om personligheden [personskapet, o.a.], adskiller Singers menneskesyn sig mærkbart fra Lockes'. Desuden vidner Regans position frem for alt om den grundlæggende forskel mellem en utilitaristisk, konsekvensetisk liberalisme og de naturlige rettigheders liberalisme.

Ferrys diskussion af dyrerettighedsteoriens bånd til de menneskelige rettigheders liberalisme indbefatter yderligere et aspekt, nemlig naturkontraktstanken. Den vækker en stærk reaktion hos ham.

Tanken om, at man skulle kunne tilføje en naturtraktat til menneskerettighedserklær ingen er filosofisk set meget lidt stringent. Der findes en åbenbar diskontinuitet mellem begge disse traktater. I den juridiske humanisme kan naturen kun optræde som objekt og aldrig som subjekt (Ferry (1997), 165).

Dyreretsteorien er i Ferrys øjne et specialtilfælde af dét paradigmatiske tilfælde, dybdeøkologien udgør med dens selvmodsigende argumenter for en naturtraktat. Han mener, at kontraktmetaforen er meget uegnet, når det gxlder om at genoprette naturens rettigheder $\mathrm{i}$ opposition til netop den antropocentriske logik, der lå bagved tankerne om en samfundskontrakt. Ifølge Ferry ligger der en logisk fejlslutning indlejret $i$ selve kernen af det dybdeøkologiske ræsonnement.

Denne bristfældige logik genfindes i dybdeøkologiens argumenter for rettigheder, når de forestiller sig, at det gode indgår $\mathrm{i}$ tingens væren, glemmer de, at enhver vurdering, inklusive vurderingen af naturen, er et menneskeligt fænomen, $o g$ at enhver normativ 
etik derfor er humanistisk eller antropocentrisk i en eller anden form (...) Dybdeøkologien glemmer, at det er dem, der i egenskab af mennesker værdsætter naturen og ikke omvendt, at det er umuligt at ophæve dette subjektive eller hu-manistiske moment og pro-jicere en egenværdi på verden (Ibid, 167).

Naturkontrakten, i betydningen at tildele naturen en iboende værdi, må være antropocentrisk set med humanisten Ferrys øjne. Ud fra hans perspektiv kan en juridisk kontrakt, i den udformning biocentristerne forestiller sig, ikke være mulig, eftersom der $\mathrm{i}$ en sådan traktat ikke findes nogen gensidighed, beroende på at naturen ikke kan betragtes som en agent, et juridisk subjekt. Ud fra et dyreretsperspektiv handler naturkontrakten om at ophøje dyrene til en jæunbyrdig part, der til stadighed står på samme niveau som det menneskelige subjekt. I Ferrys øjne er dybdeøkologiens tanke om naturkontrakten endnu mere tvivlsom. Dette på grund af, at en kontrakt $\mathrm{i}$ juridisk forstand ikke er mulig ud fra dybdeøkologiens syn på mennesket. Ferry har ret for så vidt som visse dybdeøkologer $i$ deres iver efter at indstifte naturen som retssubjekt og modpart $i$ en naturtraktat ikke indser, at det syn på mennesket og naturen, dybdeøkologien er fortaler for, udelukker kontrakttanken. Men han overser, at dybdeøkologien er en samling af heterogene opfattelser. Den dybdeøkologi, Naess repræsenterer, afviser kon-sekvent forestillingen om dualismen mellem mennesket og naturen. Denne grundtese er, at mennesket og naturen dybest set er ét gennem identifikationsprocessen. Og Per Ariansen sigter netop til Naess når han påpeger, at der i det dybdeøkologiske perspektiv ikke kræves nogen eksplicit kontrakt for at menneskets fællesskab med alt liv foreligger (Ariansen (1993), 186).

Er en ikke-metafysisk og ikke-tyrannisk humanisme da mulig? Og hvordan forener man frihed $\mathrm{og}$ tradition, omsorg for naturen og en humanistisk kultur?

Ferry hævder, at det er muligt at anvise tænkningen en vej som forsvaret for en naturvenlig humanisme, og en demokratisk økologi, kræver. Han mener, at det præliminære humanistiske standpunkt hverken bør være den cartesianske eller den utilitaristiske antropocentrisme eller dybdeøkologien.

Det er ud fra dette perspektiv hinsides dybdeøkologien men også cartesianismen og utilitarismen, at dagens humanister ifølge Ferry bør

udarbejde en fænomenologi om de menneskelige tegn i naturen, for at komme til klarhed over, hvad der kan og bør værdsættes i naturen (Ferry (1997), 179). 
Ferry hrvder, at nutidens humanister bør tilkende naturen en vis værdighed på grund af

de sider af naturen, der allerede fremtræder som menneskelige, og som knytter an til de idéer, vi værdsætter højest: frihed, skønhed og endemålsrettethed (Ibid, 179).

Han opfordrer også humanisterne til at vise fronesis (antikkens velkendte besindelse) i omgangen med naturen.

Ferrys slutning er en intern kritik af, at den antropocentriske tradition skulle gøre det muligt for os at imødegå den økologiske omsorg, uden at give afkald på vore demokratiske principper og på oplysningsarven. Ferry taler for en humanisme, der er bundet sammen med en moden politisk reformisme, og for demokratiske humanister, der har indset, at politikken $i$ et sækulariseret demokrati i sidste ende må forlade sit religiøse skød. I stedet for at skabe nye store messianske projekter, bidrager disse demokratiske intellektuelle til

at omorganisere, klargøre og indgribe $\mathrm{i}$ de store debatter, medborgerne, efter at være trådt ud af puberteten, u-undgåeligt kommer til at fordre (Ibid, 175).

\section{Sammenfattende kommentarer}

Jeg vil afslutte med nogle sammenfattende påpegninger. Jeg mener, at den samtidige debat mellem humanisterne og biocentristerne lærer os, at man ikke kan gennemtænke spørgsmålet om forholdet mellem menneske og dyr, uden at fundere over problemet, hvem eller hvad der er det moralske subjekt.

I artiklen redegør jeg for de zoofile biocentristers og humanisternes forskellige måder at betragte det moralske subjekt på.

1. Singers utilitaristiske perspektiv, hvor kriteriet for det moralske subjekt er evnen til at lide. Respekten for alle følelsesvæsener skulle kunne grundlægges i lidelsens realitet. Følgen er, at grænsen for det etiske fællesskab skærer tværs igennem arterne. Den cartesianske antropocentrisme overskrides, men der er nxppe tale om en fuldbyrdet biocentrisme.

2. Regans bestemmelse af et moralsk subjekt, der bygger på idéen om livets ukrænkelighed. Han drager ingen tydelige grænser for det etiske fællesskab: alle levende væsner kan betragtes som livssubjekter. Mennesket, ligesom dyrene, får en egenværdi i egenskab af livssubjekt og ikke som indehaver af fornuft (Locke) eller autonomt moralsk subjekt i Kants forstand.

Ferrys, Kemps og Nordins fundamentale tiltro til mennesket som et moralsk suverænt væsen farverstærkt deres kritik af Singers og 
Regans standpunkter. Alle tre mener de, at disse to dyreretsfilosoffer af vilkårlige grunde forsøger at ophrve al moralsk skelnen mellem menneske og dyr. Ferry, Kemp og Nordin slår fast, at Singer og Regan ikke giver noget overbevisende svar på spørgsmålet om, hvilke kriterier vi skal fastsætte for, at et dyr skal kunne nyde moralske og juridiske rettigheder. Alle tre er bevidste om, at cartesianismens foragt for naturen udgør et reelt problem og tager afstand fra den. De medgiver dog, at dyreretsfilosoffernes generelle angreb mod humanismen rammer den cartesianske humanisme.

Ferry, Kemp og Nordin forklarer forholdet mellem menneske og dyr ud fra uligheden. De fremholder, at uligheden udgør et grundlag for menneskets respekt for dyrene. Derimod er deres forståelse af uligheden ikke identisk, hvilket delvist beror på, at de er skolede inden for forskellige filosofiske traditioner. Ferry mener, at uligheden manifesteres i friheden. Han medgiver, at der findes en vis kontinuitet mellem dyr og menneske i spørgsmålet om evnen til at opleve smerte, men når det gælder friheden, "åbner der sig et svælg imellem dem". Ifølge Ferry misforstår Singer den rousseausk-kantianske etik og placerer den fejlagtigt sammen med den fornuftsbaserede cartesianske etik. Men i den kantianske tradition er det ikke lidelsen eller fornuften, der gør mennesket til et moralsk subjekt, men friheden. Kants tanke om, at dyret er analogon til et frit væsen, tjener for Ferry som en forklaring på menneskets forpligtelse over for dyrene. For Kemp udgøres uligheden i første omgang af menneskets evne til helhedssyn på naturen, dets erfaring af virkelig tid og en udvidet orientering i tiden. Disse egenskaber pålægger mennesket et ansvar for naturen. Kemp betoner, at respekten for livet må grundlægges i det menneskelige livs ukrænkelighed, hvilket omfatter både personen og dennes kropslighed. Han fastslår, at etikken bør udgå fra respekten for den menneskelige person. Idéen om den ukrænkelige person forbliver etikkens grundlag, selvom denne idé udvides "så den bliver til en idé om hele den levende verdens ukrænkelighed". Nordin vælger fornuftsegenskaberne som et både biologisk og moralsk adskillende kriterium. Han betoner, at man bør tage hensyn til dyrene, uden at lade den moralske afstand mellem menneske og dyr ophæves.

Hvad gælder filosofiske referencer og inspirationskilder, afviger Nordin tydeligt fra Ferry og Kemp, der står hinanden ganske nær. Ferry og Kemp havner dog på kollisionskurs hvad gælder bedømmelsen af Hans Jonas' filosofi. Kemp lader sig inspirere af den mand, Ferry kritiserer hårdt 3 .

Der er også andre forskelle. F.eks. erFerryog Nordin civilisationsoptimister og fremskridtsvenlige. Kemp er derimod en forsigtig 
civilisationskritiker. Hans indstilling til teknologien er snarere ambivalent end fjendtlig. Han fornægter ikke fremskridtet, men mener, at troen på det behøver en filosofisk-etisk vejledning.

Man mærker dog, at trods en dyb konflikt mellem de zoofile biocentrister og humanisterne er de filosofiske grunde til deres måder at betragte forholdet mellem menneske og dyr på ikke helt uforenelige. Singer og Regan deler individualismen med humanisterne. De bryder heller ikke helt med forestillingen om en dualisme mellem menneske og dyr. Dybdeøkologiens holistiske antagelser er nødvendige for at kunne annullere den. For dybdeøkologer er mennesket og naturen dybest set ét.

De zoofile biocentrister har deres referencesystem $i$ den liberal-demokratiske tradition og forholder sig aktivt til humanismen. Dybdeøkologien knytter i stedet an til en østerlandsk filosofi og til panteistiske strømninger inden for vesterlandsk tænkning.

\section{Oversat fra svensk af Tobias Hagens}

\section{Noter}

${ }^{1}$ Nash (1989), 12. For at finde belæg for sin påstand opregner Nash en række afgørende parlamentariske beslutninger om nyvundne rettigheder for f.eks. slaver (Emancipation Proclamation 1863), kvinder (Nineteenth Amendment, 1920), den oprindelige amerikanske befolkning (Indian Citizenship, 1924), arbejdere (Fair Labor Standarts Act, 1938), afroamerikanere (Civil Rights Act, 1957), naturen (Endangerede Species Act, 1973). Forud for alle disse love er gået de respektive bevægelsers kamp for at indføre dem. Nash påpeger, at ligesom abolitionisterne, som i midten af 1800tallet kæmpede for slaveriets afskaffelse, og markerede hvor grænsen for den amerikanske liberalisme dengang gik, viser den økologiske bevægelse hvor grænsen for kravet om rettigheder går idag for den amerikanske liberalisme.

${ }^{2}$ Ibid., s. 39. Nordin påpeger, at "Det er muligt at enkelte chimpansefostre ved hjælp af genterapi, hjernekirurgi og specialtræning skulle kunne bringes til at kommunikere med et sprog, tænke abstrakt, fælde moralske domme. Men et sådant væsen er ikke længere chimpanse, eftersom den ikke deler de adaptioner, der er typiske og inhærente i denne art".

${ }^{3}$ For Kemp er Jonas en reference m.h.t. hans egne tanker om bioetikken. Men til forskel fra Jonas vil han overvinde modsætningen mellem en antropocentrisk og en biocentrisk etik. Kemp mener, at Jonas' afstandsetik bør kompletteres af nærhedsetikken, der ikke må trænges bort af afstandsetikken. Ferry tolker derimod Jonas' ansvarsetik i naturalistiske termer. Han hævder, at Jonas begår en såkaldt naturalistisk fejlslutning, når han udleder moralen af naturen. Ferry påberåber sig Paul Ricoeur, som mener at Jonas må acceptere et humanistisk moment af kantiansk art, ellers opfattes mennesket som 
evolutionens højdepunkt snarere end som et frit moralsk subjekt. Ferry mærker hos Jonas dybdeøkologiens logik: at spørge til den retsbaserede moderne humanisme, for at nå frem til idéen om, at naturen har en egenværdi og som sådan er værdig til respekt.

Kemp og Ferry har også forskellige syn på Jonas' kritik af teknikken. Ifølge Kemp stiller Jonas retteligen spørgsmål om, hvor man skal sætte grænser for videnskaben og teknikken, men desværre opbygger han sit svar på frygtens begreb. Kemp mener, at grænsen bør sættes af etikken og af det kantianske menneskesyn. Ifølge Ferry vil Jonas gøre frygten til et grundprincip for politikken. I første omgang fremhæver Jonas frygten frem for teknikken, "eftersom den er nær ved at frigøre sig fra menneskets kontrol". For Jonas bliver frygten en moralsk pligt og et videnskabsprincip. En pligt, eftersom vi ikke må risikere mulighedsbetingelserne for menneskelighedens og livets eksistens. Frygten bliver også en slags vejviser, der lokaliserer og graderer de farer, inden for hvilke de samtidige og næstkommende generationer står.

\section{Litteratur}

Ariansen, Per (1993): Miljofilosofi. En introduktion. Nora: Nya Doxa.

Egonsson, Dan (1993): Om dödandet och utbytbarheten av personer. In Filosofisk. Tidsskrift: 2.

Ferry, Luc (1997): Den nya ekologiska ordningen. Stockholm.

Kemp, Peter (1991): Det oersättlige.

Stockholm.

Locke, John (1992): Två avhandlinger om styrelseskicket. Idéhistorisk läsebok, band 2. Hedemora.

Nash, Roderic (1989): The Rights of Nature. London.

Nordin, Ingemar (1997): Djur är inte människor. En filosofisk granskning af veganismen. Stockholm.

Ohlsson, Richard (1993): Anmeldelse af Singers bog Djurens frigörelse. In Filosofisk tidsskrift: I, 57-61

Regan, Tom (1979): An Examination and Defense of One Argument Concerning Animal Rights. In Inquiry: 22.

Regan, Tom (1998): Djurens rättigheter, Forord til den svenske udgave. Nora: Nya Doxa.

Singer, Peter (1979): Killing Humans and Killing Animals. In Inquiry: 22.

Singer, Peter (1992): Djurens frigörelse. Nora, Nya Doxa.

Singer, Peter (1996): Praktisk etik. Sverige. 